\title{
The Tea Party is Half Right
}

\section{Amitai Etzioni}

Published online: 25 March 2011

(C) Springer Science+Business Media, LLC 2011

My liberal friends - and I have some left, at least until this article is published - tell me that the Tea Party followers are a bunch of racist, homophobic, know-nothing, white, lower-class, gun-toting hicks. About the nicest adjective penned by liberals about the Tea Party is calling them a "libertarian mob." But drawing on 50 years of sociological study of American society, I urge one and all not to dismiss in this way a major part of the American public. The Tea Party is viewed favorably by more Americans (41\%) than either the Democrats (35\%) or the Republicans (28\%) according to a 2009 public opinion poll. ${ }^{2}$ And, according to exit polls, Tea Party's supporters numbered about four out of every ten voters in the 2010 midterm elections. ${ }^{3}$ The Tea Partiers obviously played a significant role in the 2010 elections, and are likely do so again in the 2012 election, starting as soon as the GOP nomination battle takes off. True, in the longer run, I predict they will go the way of once-feared groups such as the John Birch Society and the Moral Majority - both of which were once considered a major threats to American democracy, and both of which changed the course of the nation to some extent, but were eventually absorbed by it.

\footnotetext{
${ }^{1}$ Mark Lilla, "The Tea Party Jacobins," The New York Review of Books, May 27, 2010.

2 "WSJ/NBC News Poll: Tea Party Tops Democrats and Republicans," Wall Street Journal, December 16, 2009. http://blogs.wsj.com/ washwire/2009/12/16/wsjnbc-news-poll-tea-party-tops-democratsand-republicans/.

${ }^{3}$ Alan Fram, "Exit poll: Ailing economy, tea party fuel GOP," The Washington Post, November 3, 2010.
}

A. Etzioni $(\bowtie)$

The George Washington University,

1922 F St. NW, Room 413,

Washington, DC 20052, USA

e-mail: etzioni@gwu.edu
I find it particularly surprising that several observers hold that the Tea Party is an artificially-generated force, funded by shadowy conservative donors and whipped into a frenzy by right-wing media personas like Glenn Beck and select other demagogues. Thus, Paul Krugman writes that "the tea parties don't represent a spontaneous outpouring of public sentiment. They're AstroTurf (fake grass roots) events, manufactured by the usual suspects. In particular, a key role is being played by FreedomWorks, an organization run by Richard Armey, the former House majority leader, and supported by the usual group of right-wing billionaires. And the parties are, of course, being promoted heavily by Fox News." ${ }^{4}$ However, there are several strong reasons for large segments of the American public to be very angry, frustrated, and worried about the future. The media is locked into a misleading figure when it keeps referring to the unemployed as roughly $10 \%$ of the labor force. Actually, this number reflects only those who actively seek work. One must add to this the millions who have stopped looking for work and those who find less work then they feel they need. ${ }^{5}$ If one includes these groups, the actual proportion of the population which is unemployed, underemployed, or discouraged is closer to $16 \%{ }^{6}$ Also, one should take into account that many have experienced unemployment, finally found some workalbeit for less pay and with fewer benefits than they previously had - and still live with the fear of falling back

\footnotetext{
${ }^{4}$ Paul Krugman, "Tea Parties Forever," The New York Times, April 13, 2009.

${ }^{5}$ Bureau of Labor Statistics, "Table A-15. Alternative measures of labor underutilization," October 8, 2010. http://www.bls.gov/news. release/empsit.t15.htm

${ }^{6}$ Mary Engel, "The Real Unemployment Rate? 16.6\%," MSN Money, June 4, 2010. http://articles.moneycentral.msn.com/learn-how-to-invest/ The-real-unemployment-rate.aspx
} 
out of work. When I finished my military service, I could not find work for several weeks. I still feel the sting of not knowing whether I'd be able to pay for my next meal or whether I'd end up sleeping on a bench - to say nothing of the humiliation of rejection by one potential employer after another. Being unemployed stays with you. Now add to these the millions who lost their home, their only asset, often after being manipulated by some broker, and those who lost most of their retirement eggs, and you find a very large number of Americans who have very good reasons to be angry - and who would be angry even if all the TV personalities had never said a word.

Now add to this the undeniable fact that much of the rescue money did flow to banks, to their shareholders, and to Wall Street, who paid their executives and traders what were fairly called "obscene" bonuses, and you do not need much more to disgust people. Oh, I know that "we had to save the banks, because otherwise we would have fallen into a 1930s-like depression." Even if this is true, the terms under which financial institutions were guaranteed trillions of dollars (through government lending, government insurance of debt, and government investment) ${ }^{7}$ should have been much stricter. After all, they were one inch from sinking, and the public was throwing them lifelines. The government could have insisted that the shareholders agree to make the public whole after the banks and Wall Street recovered, and it could have demanded that their executives agree to forego bonuses and take a pay cut until that day. (Actually, I believe a rather different approach was possible, starting with Main Street. If the same amount set aside for TARP - the rescue package — had been divided among all American households in the form of a coupon that could be used only to pay down one's mortgage, the money would have ended up in the same financial institutions that TARP did, but all Americans would have benefited. The coupons would be tradable, so those who did not have a mortgage could sell them. For those who argue that the banks needed cash in a hurry, one could have put, say, a 90-day expiration date on the coupons. The information that some $\$ 700$ billon were on their way to the banks would surely have prevented those who held their shares and bonds from letting them go under.)

Given the depth and nature of the resulting angerwhich I and many on the left share - the Tea Party provides a very surprising outlet and one that attests to the very resilient nature of the American polity. Several of my colleagues, who feel that I don't get it, strongly urged me the read the 'seminal' essay on the Tea Party by Mark Lilla,

\footnotetext{
${ }^{7}$ Interactive Graph: "Adding Up the Government's Total Bailout Tab," The New York Times, February 4, 2009. http://www.nytimes. com/interactive/2009/02/04/business/20090205-bailout-totals-graphic. $\mathrm{html}$
}

published in the New York Review of Books. Professor Lilla is given a bit to over-generalizations. For instance, he writes, "Democrats were day-trading, Republicans were divorcing," which is a great line, but must be discounted before one uses it to note that the two major parties are less different than they used to be. And it is already clear that his May 2010 prediction - that the Tea Party will dissolve after a few symbolic victories - will not hold. Their November victories are much more than symbolic, and they are far from done. However, this is small potatoes compared to a truly stunning misperception of the Tea Party. Lilla calls them (and hence the name of his essay) the New Jacobins. Jacobins, for those not up on their French history, imposed a reign of terror on France, guillotining not merely the aristocracy but also their opponents. The Jacobins set up paramilitary sans-culotte forces among the urban poor to help enforce the government's decrees against farmers who would not surrender grain. The sansculottes rioted and beat to death clergymen, nobles, and anyone else imagined to be anti-revolutionary.

In sharp contrast, $\underline{\text { so far }}$ the Tea Partiers have worked almost completely within the democratic system. (The media made much of two incidents of violence at Tea Party events-Joe Miller's private security team detained a journalist, and one protester at a Rand Paul rally was thrown to the ground and stomped on by a Paul supporter.) But otherwise, the Tea Partiers have practiced-believe it or not-politics as usual! Despite their deep-seated contempt for politicians and the way politics is done these days, they chose to run candidates in primaries, raised funds, knocked on doors, set up voter banks, got the vote out, and followed suit in the general elections. Indeed, it is to the credit of American democracy - and, frankly, to the Tea Party - that their very justified anger has been expressed in such a legitimate and institutionalized manner.

One need not consider what happened recently in the streets of Greece or France when their people faced cutbacks to witness where the Tea Party did not go. One can stay in these shores and revisit the riots by the 1999 anti-globalization protestors in Seattle, who looted store fronts and set bonfires in the streets. Not to mention the Weathermen and the Black Panthers, and before that, the KKK.

Better yet, although civil disobedience is a much more benign mode of protest than acts of violence, the Tea Party has almost completely refrained even from this kind of unconventional political action. We would be in a rather different place, if, for instance, the Tea Party convinced a million Americans that the federal income tax is unconstitutional and encouraged such people to put their tax money in escrow, refusing to pay until the courts ruled on their petition. I assume that the U.S. Supreme Court would have sided with the government; however, given how ideological 
it has become, I would not bet my bottom dollar on such an outcome.

Most of the Tea Partiers are white. And I am sure they include a fair number of people whose views about race, sexual orientation, and much else are deeply troubling - and, as Peter Berkowitz writes, it has "its share of clowns, kooks, and creeps." ${ }^{8}$ Three quarters of Tea Party supporters hold that "if blacks would only try harder, they could be just as well off as whites." However, the presence of such views within Tea Party circles - views which, I hate to report, you would find elsewhere in the American public, and elsewhere in American history - do not comprise the main Tea Party message. It does not call for canceling bussing, Head Start, or setasides for minorities any more than most other programs that generate public outlays.

A study of about 250 signs at one Glenn Beck rally found that almost all of them focused on spending and economic issues. There were only a few offensive messages - only $5 \%$ of the signs mentioned the president's race or religion. ${ }^{10}$ Critics of the study hold that this is not an accurate sample. At least one must admit that the Tea Partiers are rather self-disciplined, which you cannot say about other protesting groups, and which surely belies their image as a bunch of wild rednecks.

Several reporters in the media on the Tea Party scoff at the way it is organized, or rather, not organized. Harvard historian Jill Lepore calls the movement "scattered, diffuse and confused."11 The Tea Party, reporters find, is not a party at all. Actually, it includes several organizations such as Tea Party Patriots and the Tea Party Express. It does not have a clear national leader but is run mainly by a bunch of local leaders. And the Tea Party followers are found to differ considerably from one another; some are radical libertarians, some are social conservatives. All this seems to be quite true. However, if one revisits the same information and then adds the information found in such excellent year-long study of the Tea Party by New York Times reporter Kate Zernike, published in her book Boiling Mad, one notes that the Tea Party has all the marks of a social movement: enthusiastic volunteers; spontaneous local leaders; a strong sense of shared values and of fellowship; and a commitment to action. ${ }^{12}$ Anyone who participated in such a movement, as

\footnotetext{
${ }^{8}$ Peter Berkowitz, "Why Liberals Don't Get the Tea Party Movement," The Wall Street Journal, October 16-17, 2010.

9 James Crabtree, "Reading the tea leaves," Prospect (UK), October 30, 2010.

${ }^{10}$ Amy Gardner, "Few signs at tea party rally expressed racially charged anti-Obama themes," Washington Post, October 14, 2010.

${ }^{11}$ Jill Lepore, The Whites of Their Eyes: The Tea Party's Revolution and the Battle Over American History, (Princeton: Princeton University Press, 2010), 14.

${ }^{12}$ Kate Zernike, Boiling Mad: Inside Tea Party America (New York: Times Books, 2010).
}

I did extensively in the movement against the war in Vietnam, finds that they are similarly disorganized, but that does not prevent them from being a major force in American public life.

\section{Wrong Address vs. No Address}

While the Tea Partiers' sense of anger is more than justified, and their basic sense that there is something terribly wrong with the way our government operates is valid, they profoundly misdirect their ire. The main issue is not the size of the government, which is rather limited compared to that of other modern democracies. (Recent estimates indicate that the U.S. government's spending equals about $26 \%$ of the country's GDP, while Germany spends $29 \%$, Finland $35 \%$, the UK $43 \%$, and France $45 \%{ }^{13}$ ) The problem, rather, is that the government is captured by special interests and often serves them rather than the public at large or shared public goods.

Take the health care bill, which the Obama administration considers its greatest contribution to American society. Disregard for a moment that this was not what America needed most in 2009 and that it ate up a good part of President Obama's political capital. Look at the way the bill was fashioned. First of all, the White House promisedsecretly - the private hospital lobby not to even consider a public option, in order to gain its support. ${ }^{14}$ Next, they cut a deal with the pharmaceutical industry (to not allow Americans to purchase low cost drugs from other countries). ${ }^{15}$ And from then on, a whole variety of deals were cut with this or that member of Congress to pay off the special interests closest to their campaign finance chest. The one that got most attention was a deal made with Senator Nelson (later abandoned) that committed the federal government to pick up the tab for any increase in Medicaid costs in his home state of Nebraska, while all other states would have to continue to draw on state funds to pay for the cost increases.

Now, those who closely follow American politics no longer see anything wrong with this way of running the country. Politics, they say, requires making deals and compromises. However, this is hardly what happened in this case-and what happens day-in and day-out in

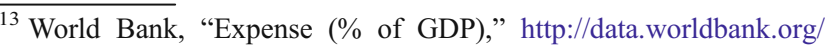
indicator/GC.XPN.TOTL.GD.ZS

${ }^{14}$ According to "Obama Is Taking An Active Role in Talks on Health Care Plan," New York Times, August 13, 2009. The understanding of both sides that the deal precluded a public option in the final bill was confirmed by the Times story's reporter, David Kirkpatrick, on The Ed Show, MSNBC, March 15, 2010, http://www.msnbc.msn.com/id/ 35892799/ns/msnbc tv-the ed show/.

${ }^{15}$ Alicia Mundy, "Measure to Allow Drug Imports Fails," The Wall Street Journal, December 16, 2009.
} 
Washington. The deals are not among major constituencies representing the public, whose influence is roughly measured by the size of the electorate they represent. The deals are, most of the time, among narrow special-interest groups, those that are able to raise more campaign contributions than others, those with the deepest pockets. The fact that banks and brokerage firms got their way-while millions of homeowners and investors lost-is all too emblematic.

Moreover, the deals do not concern some marginal adjustments to get various groups to buy in, but entail major departures from what would benefit people and what independent observers see as in the public interest. Oil companies win, drivers lose; big business wins, consumers lose; cereal-makers carry the day, children eat sugar; armsmakers win, and taxpayers pay for weapons which the Department of Defense and the White House find we do not need. The 70,000 page-long federal tax code mainly contains one page after another of exceptions and loopholes. ${ }^{16}$ These include tax breaks, preferences, and credits, which if eliminated, would save $\$ 45$ billion over 10 years ${ }^{17}$ and a loophole for hedge funds that, if eliminated, would save $\$ 25$ billion over 10 years. ${ }^{18}$ Attempts to water down or eliminate both of these tax breaks have stalled in the face of opposition from industry representatives. ${ }^{19}$ Wall Street banks received an $\$ 80$ billion dollar tax break on employee bonuses - right after receiving costly taxpayer bailouts. ${ }^{20}$ Members of the House committee which approved a major loophole exempting auto dealers from regulation in the financial reform bill received a total of $\$ 330,500$ from the National Automotive Dealers Association in the 2010 elections-more than the industry group gave to any other House committee. ${ }^{21}$ Similarly, as the Department of Education has tried to draft regulations for for-profit colleges (which have been accused of profiteering from federal loans at taxpayer expense), it has

\footnotetext{
16 "The joy of tax," The Economist, April 8, 2010. http://www. economist.com/node/15867984?story_id=15867984

${ }^{17}$ Sima J. Gandhi, "Eliminating Tax Subsidies for Oil Companies," Center for American Progress, May 13, 2010. http://www.americanprogress.org/issues/2010/05/oil_company_subsidies.html

18 John Ydstie, "Senate Seeks To Close Hedge Fund Tax Loophole," NPR, June 14, 2010. http://www.npr.org/templates/story/story.php? storyId=127728787.

${ }^{19}$ See David Kocieniewski, "As Oil Industry Fights a Tax, It Reaps Subsidies," New York Times, July 4, 2010 and "S.3405-Close Big Oil Tax Loopholes Act," http://www.opencongress.org/bill/111-s3405/ show; as well as Chuck Marr and Gillian Brunet, "Compromise Provision to Narrow 'Carried Interest' Tax Loophole Should Not Be Weakened Further," Center on Budget and Priority Priorities, June 9, 2010. http://www.cbpp.org/cms/index.cfm?fa=view\&id=3209.

${ }^{20}$ Lynnley Browning, "With Bigger Bonuses, Another Upside for Banks," New York Times, January 1, 2010. http:/www.nytimes.com/ 2010/01/01/business/01bonus.html?ref=business

21 "National Automotive Dealers Association: Congressional Committees," Center for Responsive Politics. Accessed March 1, 2011. http://www.opensecrets.org/orgs/congcmtes.php?id=D000000080\& cycle $=2010$.
}

had to water down and delay its efforts in the face of intense opposition from the Association of Private Sector Colleges and Universities (APSCU). APSCU more than doubled its spending in the last election cycle to just over $\$ 200,000$ including donations to members of Congress who sent a letter to the Secretary of Education in March 2010 expressing "serious concerns" about the proposed regulations. ${ }^{22}$ The pages of two books on the subject-The Money Men by Jeffery H. Birnbaum and So Damm Much Money by Robert G. Kaiser-are littered with more cases in point.

Most citizens are too busy trying to make a living, spend some time with their families, have a beer and watch football, to follow how the government got so captured. However, once in a while, when this severe perversion of our polity is highlighted as strongly as when the government bailed out Wall Street and left Main Street to wither, the masses pay mind. And they become nauseated - as they should.

The same anger and dismay could have been turned into a very constructive force - into a new progressive movement, akin to the one that led to a considerable clean-up of the government at the beginning of the $20^{\text {th }}$ century. This might have happened if, instead of dissing the Tea Partiers, the left had directed their political energy at the right targets. Much has already been written about the odd phenomenon of the way one of the most articulated and effective communicators in recent memory lost his voice once he moved into the White House. Some attribute this loss to President Obama's innate coolness, others to his arrogance.

All this may have played a role. As I see it, a main culprit was and is a fear of populism, which is risky at most times, but which is now called for. In a seminal article in The New Republic, Noam Scheiber describes a continued dialogue between President Obama and his main political strategist, David Axelrod. Axelrod argued for a more populist approach; the President was leaning toward a pragmatic one. True, rallying against the special interests and seeking to mobilize the masses against them has been often tried, and it has often failed. John Edwards tried it during the 2008 election campaign and did not get very far. Howard Dean's populism did not carry him any further. Al Gore had his populist moments but soon retreated. The reasons are manifold. Most times Americans blame themselves when the world around them crashes, rather than "The System". The GOP is quick to label populist moves by Democrats as class warfare, which scares away American voters. Above all, populism leads the special

\footnotetext{
${ }^{22}$ Letter to Secretary Arne Duncan, March 22, 2010. http://www.pbs.org/ wgbh/pages/frontline/collegeinc/etc/duncan_letter.pdf. Donation information comes from page on the Association of Private Sector Colleges and Universities, The Center for Responsive Politics. Accessed March 1, 2011. http://www.opensecrets.org/pacs/pacgot.php? cycle $=2010$ $\& \mathrm{cmte}=\mathrm{C} 00213066$
} 
interest groups under attack to pull out all the stops and go after those seeking to rein them in. The recent Supreme Court ruling in Citizens United makes this much easier than it ever was before, by removing limits on how much cash corporations can throw at those who stand in their way.

On the other hand, given the scope and nature of the Great Recession, the Democrats' failure to provide a target for the populace's deep and justified sense of frustration was and is a major and costly strategic failure. Without any address for their outrage, the voters went to where the GOP pointed them-against the government itself, rather than against those who captured too much of it.

In effect, Obama has chosen a rather dubious course. He strikes populist notes some days and makes nice with Wall Street on the others. Thus, one day he declared the bonuses obscene, and the next day he stressed that he was not against Wall Street. Some days he denies that he was anti-business, saying that he had only done what common sense demanded, ${ }^{23}$ but other days he employs lines such "I did not run for office to be helping out a bunch of fat cat bankers on Wall Street." 24 Most days, though, Obama has tried to continue to blame Bush, not the special interests, and to promise that things are on the mend, which is not the way it feels to very large segments of the American public - a sentiment on which the Tea Party draws.

Senator Obama understood during the 2008 campaign that to refocus the public's attention, one needs to repeat the same message scores of times, in scores of venues, and in as many ways as possible. This is not a course he has followed in the White House. As a result, as CNN's Gloria Borger reported, when Democratic voters were asked what the Republican message was, they regurgitated it easily and correctly. When Borger asked them what the Democratic message was, the voters couldn't respond. ${ }^{25}$ Neither can I. And the Democratic pollster Stanley Greenberg was warning, by September 2010, that the White House's talking points for the 2010 midterm campaign - that Republican policies would take the country "backwards" to the days of the Bush administration-were ineffective with voters. He was dismayed to find that the party had not changed its message. ${ }^{26}$

\footnotetext{
${ }^{23}$ Stephen J. Adler and Jane Sasseen, "Obama says he's not antibusiness,” Bloomberg Businessweek, July 31, 2009.

${ }^{24}$ Elizabeth Williamson, "Obama Slams 'Fat Cat' Bankers," The Wall Street Journal, December 14, 2009.

${ }^{25}$ Gloria Borger, Interview on "Washington Week with Gwen Ifill," PBS, October 1, 2010. http:/www.pbs.org/weta/washingtonweek/ transcript/10309.

${ }^{26}$ Peter Wallsten and Jonathan Weisman, "Pressure Builds on Obama to Shake Up Inner Circle," The Wall Street Journal, November 2, 2010.
}

\section{No (Open) Transfer Payments, Please}

Once in a while, I attend one of those private salons in Washington that are frequented by politicians. During the 2008 election campaign, practically all the Democratic candidates stopped by, including Obama, Biden, Dean, Clinton and even Gary Hart. After the elections, HHS Secretary Kathleen Sebelius stopped by to talk up the health bill. She said it would accomplish two things: insure the uninsured and reduce costs. Toward the very end of her talk, she mentioned in passing that each day 12,000 Americans lose their health insurance. Like her, the White House stressed the same points as recently as President Obama's appearance on The Daily Show in October 2010. When Jon Stewart told the president that his approach was "timid," the president responded by reminding the audience that he insured 30 million Americans.

What is wrong about such an elementary move toward basic social justice? It flies in the face of an elementary fact of American politics - and does so unnecessarily. Americans, we have know for decades, oppose transfer payments from the haves to the have-nots - but are very supportive of programs that support one and all (call them 'universals'), even if these in effect share the wealth. Thus, Medicare is very popular but Medicaid is not, despite the fact that Medicare covers almost everyone over $65 .{ }^{27}$ And Social Security is very popular while welfare is not, despite the fact that Social Security favors those with large families, mostly those less affluent, and members of minorities. Together these two "universal" programs moved many millions of Americans out of poverty. About half of seniors were impoverished in 1934, but in 2008 fewer than $10 \%$ of the elderly lived in poverty. ${ }^{28}$ The Obama healthcare bill was presented as aiming to cover the uninsured (while requiring all Americans to purchase health insurance). This runs directly into the strongly American sentiment against transfer payments. This is particularly odd, given the fact that what the bill really does is ensure that all Americans will be covered, that no American will have to worry about not being able to find insurance or lose it (with very few exceptions), and hence could be readily have been introduced as a universal, rather than as a transfer payment. Having failed to do so, no one should be surprised to find that many Tea Partiers say they do not want to pay for "them". Ron Paul, who has become popular among many Tea Partiers, has frequently argued that the government

\footnotetext{
${ }^{27}$ Medicare provides "nearly-universal coverage". See Marilyn Moon, "What Medicare Has Meant to Older Americans," Health Care Financing Review 18, no. 2 (Winter 1996), 49. http://ssa.gov/history/ pdf/WhatMedicareMeant.pdf.

28 "A look at the senior citizen safety net," Omaha World-Herald, August 15, 2010, http://www.omaha.com/article/20100815/AP/ 708159808
} 
cannot legitimately take taxes from one person to benefit someone else. $^{29}$

The same issue has arisen with the debate of jobs vs. deficits. Finding a job concerns large segments of the population-but the deficit threatens all of us and our children and grandchildren. As long as the debate is framed in these terms, reducing deficits is going to trump job creation-whether or not those jobs are green or whether they are said to fix the aging infrastructure. If the debate had been framed between those who favor more "business" - that is, a higher level of economic growth-versus those who hold that things would take care of themselves if the government just stayed out, the pro-growth forces would stand a much better chance. The Democrats at least would have escaped the opposition of those who reject transfer payment - a very large part of the American public.

Political analysis is often carried out in terms of Democrats and Republicans, two more-or-less even parties, whose fortunes swing as the independent voters change sides. However, for the issues at hand, it is crucial to note that while practically all Republicans are conservatives, many Democrats are not liberals. ${ }^{30}$ In effect, nationwide, for every liberal voter, there are two conservatives. ${ }^{31}$ And the conservative wing is growing. In this polity, transfer payments, laudatory as they may be, do not stand a prayer-unless they are folded into programs that benefit all.

\section{The Good News?}

I may as well admit up front that I am not one of those who can read the future. Indeed, I am not sure that anybody can. A year in politics is a lifetime. Much depends upon whether the economy improves and the way the war in Afghanistan unfolds. (Even this point is more complicated than it sounds. Many observers assume an improved economy will work for the Democrats. However, New York Times political analyst Matt Bai raises the possibility that the GOP and Tea Party would take credit for such an upswing, pointing to their curbing effects on the government.) If the United States lapses into a Japan-like lost decade and fails in Afghanistan, the angry masses may well lash out against the current incumbents the way they did against those who lost the election in 2010 , or support a third party, or-much worse-really take to the streets.

To the extent one can learn from the past, social movements - especially ones as fluid as the Tea Party-regularly change their form. Some are co-opted, the way the GOP establishment is trying to channel the Tea Party's energy. Others see their fervor dissipate and become ever less of a force, the way the much-feared Birch Society and Moral Majority went.

Particularly difficult to assess is how the Democratic Party and the White House will react to the shellacking they took in the 2010 midterm elections. Will they find a coherent message and one that will point the public anger to the proper address - as I see it, a populist message? And will the pushback by the special interests play in favor of this new populism, or will it defeat it?

Amitai Etzioni is a University Professor at the George Washington University and author of The Active Society and New Common Grounds, among other books.

\footnotetext{
${ }^{29}$ Zernike, Boiling Mad, 165.

${ }^{30}$ Lydia Saad, "In 2010, Conservatives Still Outnumber Moderates, Liberals," Gallup, June 25, 2010. http://www.gallup.com/poll/141032/ 2010-conservatives-outnumber-moderates-liberals.aspx.

${ }^{31}$ Ibid. 